The $B D J$ News section accepts items that include general news, latest research and diary events that interest our readers. Press releases or articles may be edited, and should include a colour photograph if possible. Please direct your correspondence to the News Editor, Arveen Bajaj at the $B D J$, The Macmillan Building, 4 Crinan Street, London N19XW or by email to bdj@bda.org

\section{Agreement on SAS contract proposals}

The British Medical Association, the British Dental Association and NHS Employers have jointly agreed proposals for a new contract for staff grade and associate specialist (SAS) doctors and dentists. SAS doctors and dentists will be balloted on whether to accept these proposals in the New Year, subject to approval from the four UK Health Departments and the Government's Public Sector Pay Committee.

Keith Altman, Chair of the British Dental Association's Central Committee for Hospital Dental Services, said, "The British Dental Association advises dentists to attend the road shows that are being organised to explain these proposals. It is for individual dentists to decide whether to vote in favour or against these proposals based on the information provided to them." Heather Lawrence, Chief Executive at Chelsea and Westminster Healthcare and chair of the NHS Employers negotiating team said, "We are delighted that we now have an agreement on the new contract."

\section{Presidents past and present}

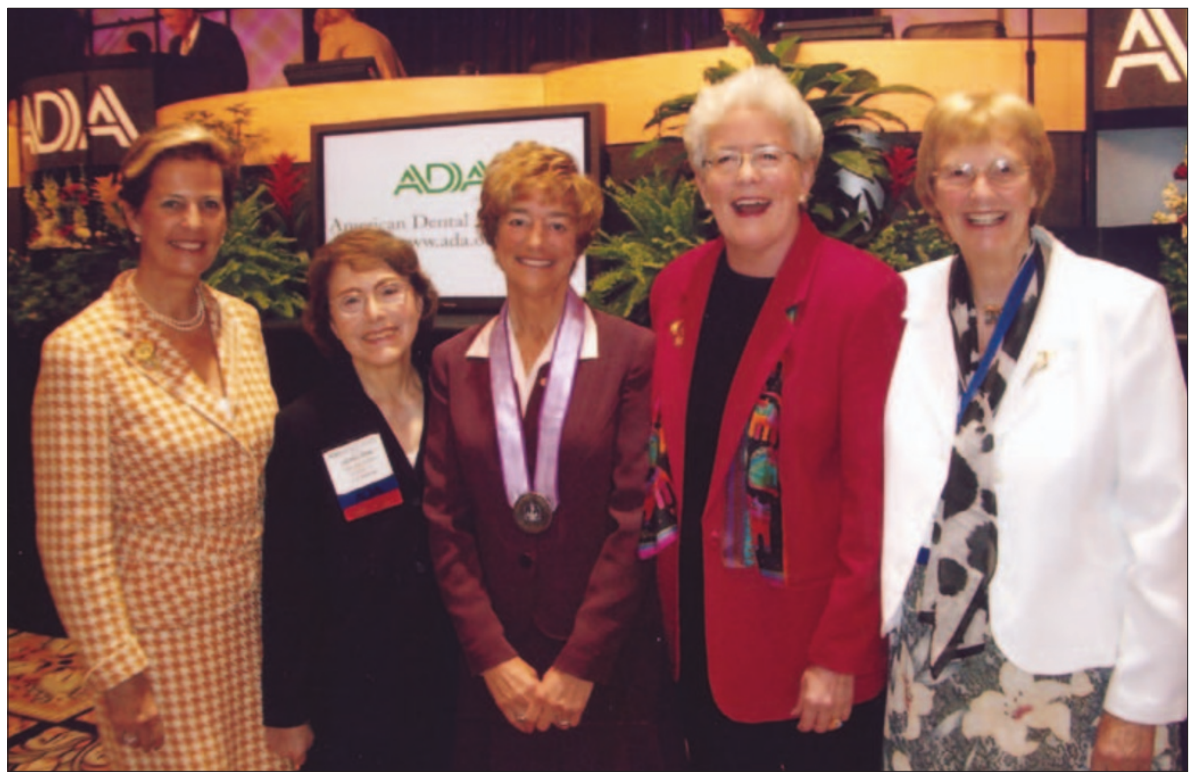

A host of presidents - many of whom were the first woman Presidents of their organisations - gathered at the American Dental Association (ADA) Conference recently in Las Vegas. Dr Kathy Roth was inducted new President of the ADA at the conference. A general dentist and a graduate of Milwaukee's Marquette University School of Dentistry, Dr Roth is just the second woman to hold the ADA's highest elective office. The first woman President of the ADA in 1992 was Dr Geraldine Morrow, who was present for the induction, as was Dr Michèle Aerden, the current and first woman President of the FDI, and Dame Margaret Seward, a former President of the BDA. The first woman President of the American College of Dentists, Dr Marcia Boyd received honorary membership of the ADA at the conference. Pictured above from left to right, Dr Michèle Aerden, Dr Geraldine Morrow, Dr Kathy Roth, Dr Marcia Boyd and Dame Margaret Seward.

\title{
GDC registration fee levels for 2007 announced
}

The General Dental Council (GDC) has confirmed the registration fee levels for 2007. The fees for 2007 will be $£ 420$ for retention, £420 for temporary registration (first and renewal), £35 per month from the month of application for first registration (£250 for Oral Surgery and Orthodontics lists only) and £105 for restoration. According to the GDC, the new levels will mean a below inflation annual retention fee (ARF) increase of $£ 11$ (2.7 per cent) for dentists.
GDC President Hew Mathewson said, "The GDC is funded entirely by registrants' fees. The Council's financial objective remains to ensure that its resources are used economically and efficiently and therefore it is taking a prudent approach in agreeing these fee increases. The small increases will enable us to ensure that adequate resources are available to finance the increased demands placed upon the Council's existing functions."
The GDC has agreed to introduce an ARF from 2008 for inclusion on the Specialist Lists. This fee will be set at £50 per Specialist List entry and the first registration fee for inclusion on the Specialist Lists will be extended to all specialities from 2008, currently this is only applicable to the oral surgery and orthodontics lists. Further information on the ARF is available on the GDC website at www.gdc-uk.org/Current+registrant/ Annual+retention+fees/. 


\section{Periodontal disease can affect organ transplant survival}

Researchers from the University of Connecticut Health Center have reported an interrelationship between periodontal and systemic inflammation in solid organ transplant recipients.

Researchers have known that inflammation plays a pivotal role in organ transplant rejection and that levels of serum interleukin-6 (IL-6) can identify individuals who are at greater risk for transplant rejection. IL-6 is a protein that is secreted to stimulate the immune response to trauma, foreign antigens, or infections, such as periodontal infection.

Once secreted, IL-6 can enter the bloodstream and circulate in an active form long enough to mediate distal effects in other tissues and organs. "Our goal was to assess the periodontal status of solid organ transplant patients to quantify the IL-6 levels in bloodstream and gingival tissues and explore their possible association with chronic periodontitis," explains Principal Investigator Anna Dongari-Bagtzoglou, Associate Professor and Chair of the Division of Periodontology at University of Connecticut Health Center.

Forty-seven kidney and cardiac transplant patients were recruited for the study, and patients had to be clinically stable, at least one-year post transplant, absent of additional systemic conditions that might elevate the systemic inflammatory status and have no history of periodontal treatment within the last year.

A group of 18 systemically healthy individuals that matched the age and sex were also recruited. All individuals received a complete clinical periodontal examination, medical records of the transplant subjects were reviewed and a blood and gingival sample were taken to quantify levels of IL-6.

"We found that in transplant patients with chronic periodontitis, bloodstream IL-6 levels were elevated compared to those with no periodontitis, and were positively associated with locally synthesised levels of IL-6 within periodontal tissue. This suggests that periodontal infections have the potential to affect systemic levels of IL-6 in this population."

In support of this, it was also found that clinical periodontal parameters such as probing depth and clinical attachment loss were independent predictors of the body's IL-6 levels. The study appears in the Journal of Periodontology.

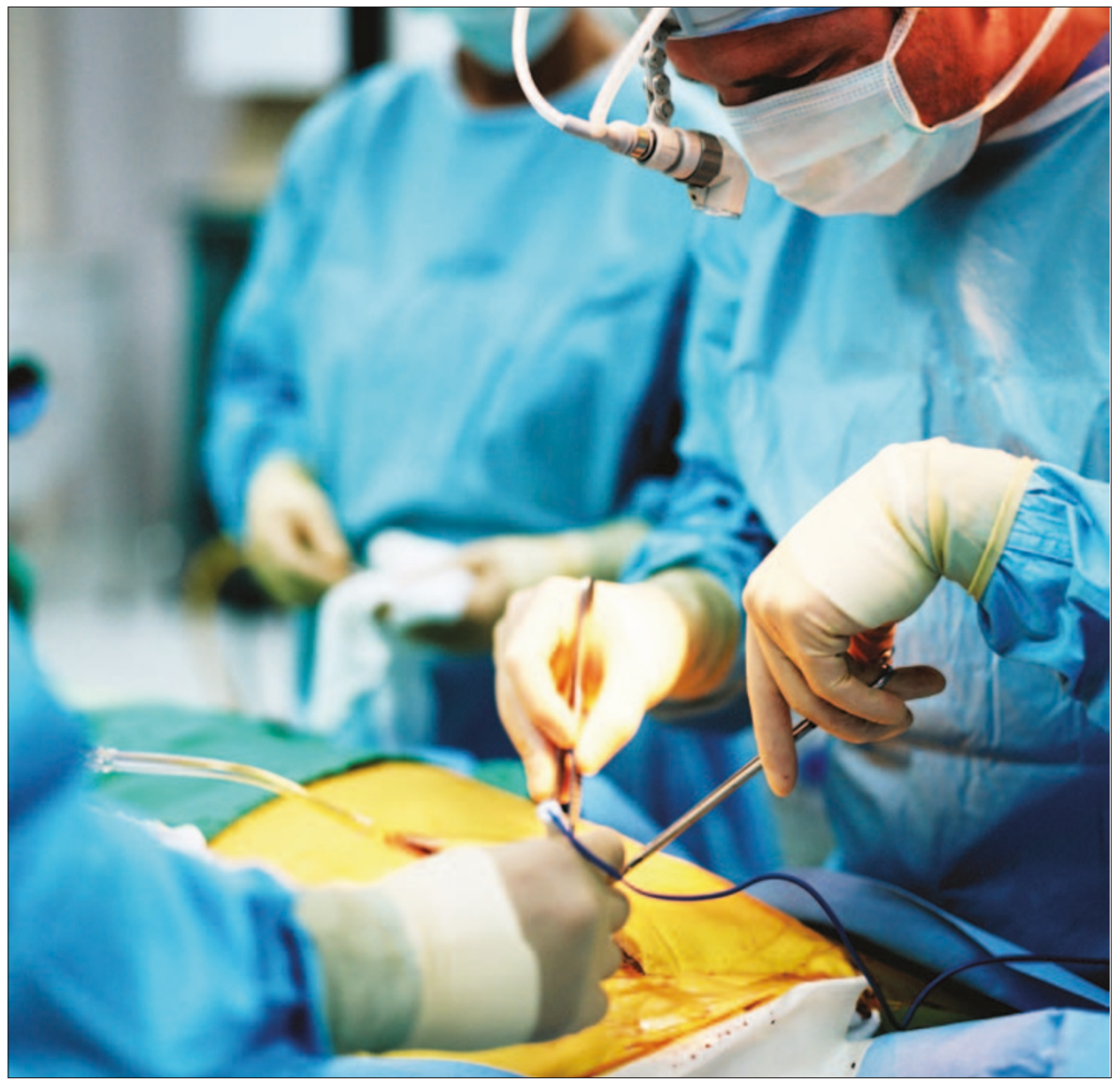

Smiles all round for new award

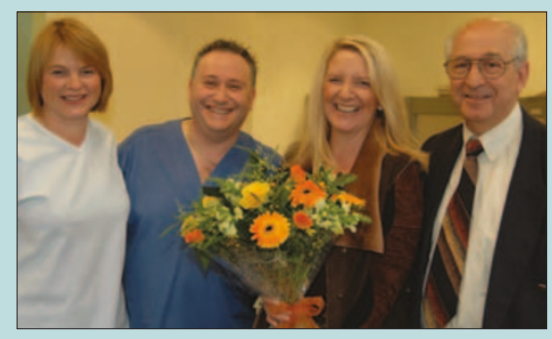

Tracey Greenfield, winner of the BOS Against the Odds Specialist Smile Award, with (left to right) Dental Nurse Lynne Sidney, Dr Joel Levy and Dr Kim Mizrahi.

An award designed to increase the awareness of the impact of orthodontic treatment on patients' lives has been set up by the British Orthodontic Society. The Against the Odds Specialist Smile Award enables patients to celebrate the successful conclusion of their orthodontic treatment by allowing them to describe why they have had treatment and what difference the outcome has made to their confidence and well-being.

The first winner of the competition, sponsored by SDS Ormco, is Tracey Greenfield who has been happily smiling for the camera since her treatment was completed in time for her 40th birthday.

Ms Greenfield said she would never smile for photographs before her orthodontic treatment because she hated her misaligned teeth. A routine appointment some years ago with her dentist Dr Joel Levy of Redbourn Dental Practice in Redbourn, Herts started her on her long but rewarding course of treatment.

She was treated by orthodontic specialist, Dr Kim Mizrahi at his practice in Gant's Hill, Essex. In the winning account of treatment, Mr Greenfield said, "Over the last three years we have worked as a team. Dr Mizrahi was so committed to helping me that I was determined to be equally as committed. I now have a smile we are both proud of and I want to say thank-you for giving me back my confidence."

Her prize was a holiday for two worth $£ 700$ and Dr Mizrahi was presented with the Against the Odds trophy at the British Orthodontic Conference. 


\section{New craniofacial care centre opens}

A modern multi-disciplinary craniofacial care facility was officially opened recently at the Eastman Dental Hospital, University College London Hospitals NHS Foundation Trust.

The Eastman Craniofacial Centre provides continuity of care for children with craniofacial deformities once they have reached 16 years of age through their transfer from Great Ormond Street Hospital, and other units, to the new out-patient centre at the Eastman Dental Hospital.

In-patient treatment is provided in the state-of-the-art facilities offered by the new UCL hospital, where Europe's largest adolescent unit is also available to facilitate the transition from children's to adult services.

The centre, which brings together the specialist expertise of eight different disciplines from across three different Trusts, will provide first class patient care in addition to specialist training and research into craniofacial deformity.

Professor Nigel Hunt, Chairman of the Division of Craniofacial and Developmental Sciences and Clinical Lead said, "We have been pushing for this facility for almost ten years and it is a very welcome development at a time of severe financial pressures".

The Consultant-led craniofacial team

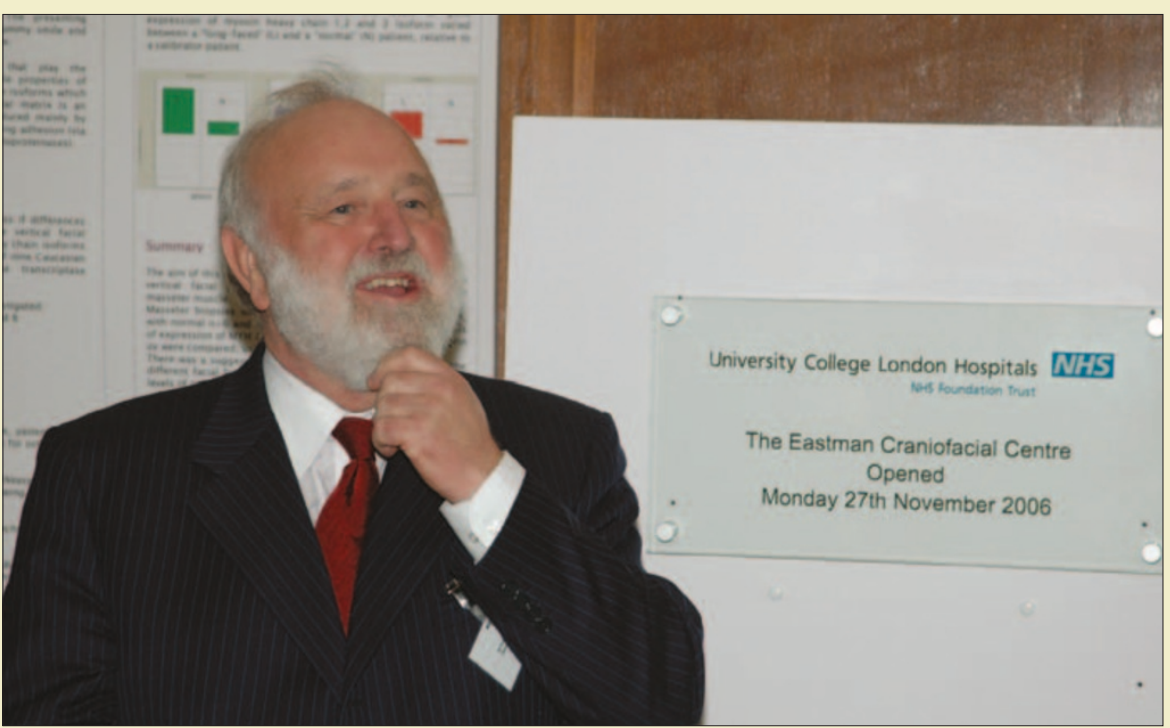

The centre was opened by the Rt Hon Frank Dobson

includes Oral and Maxillofacial surgery (Mr Tim Lloyd), Plastic and Craniofacial Surgery (Mr David Dunaway), ENT surgery (Mr Charles East), Neurosurgery (Ms Joan Grieve), Anaesthetics (Dr Viki Mitchell), Liaison Psychiatry (Dr Justin Shute), Orthodontics (Professor Nigel Hunt, Mr Rob Evans and Mr Daljit Gill) and Restorative dentistry (Ms Gwen Benny-Wilson).

The Rt Hon Frank Dobson (MP for Hol- born \&t St Pancras), who officially opened the facility, commented how valuable the centre was as it harnessed the expertise of individual specialists with first class reputations for excellence in their own fields into a cohesive team which can only be for the improved overall benefit of the patient.

More information can be found about this service by visiting 'Craniofacial Services' at www.uclh.nhs.uk.

\section{Elearning for dental students}

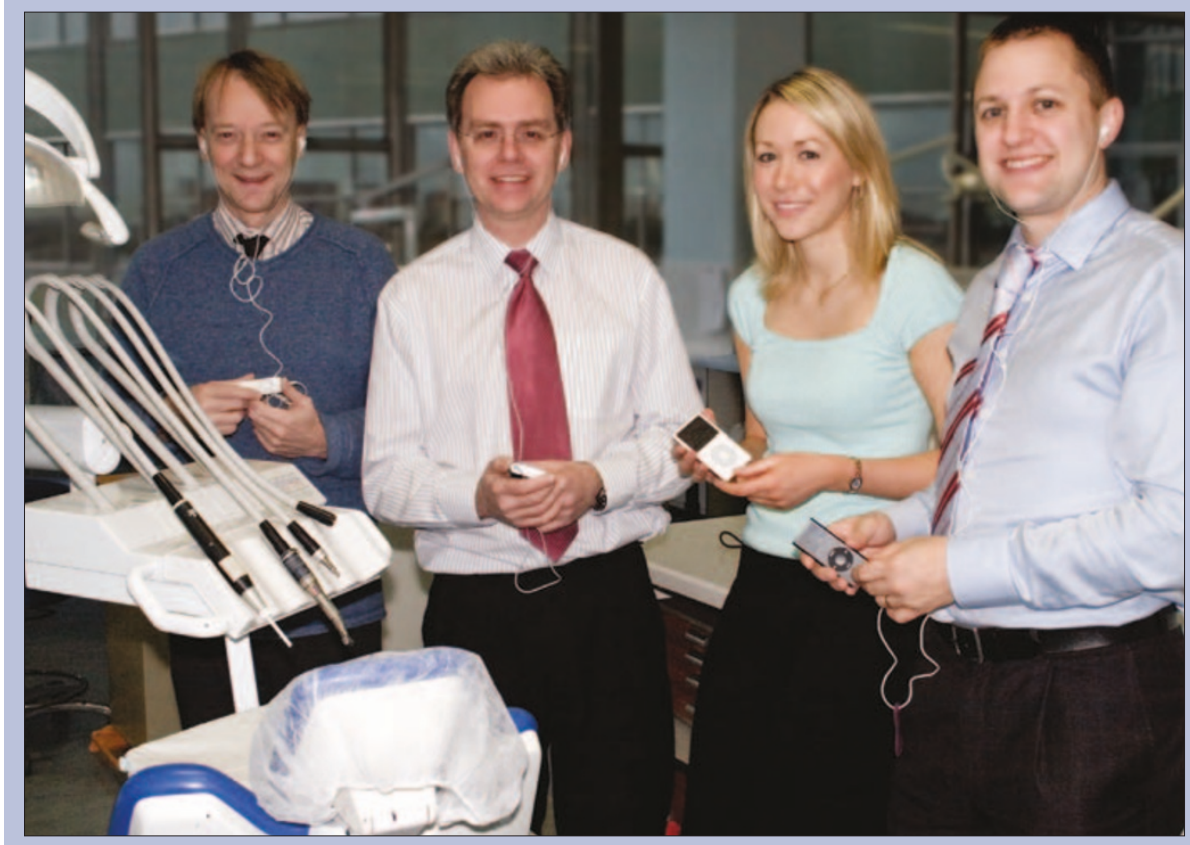

The School's Podcasting team of Giles Perryer, Damien Walmsley, Catherine Lambe and David Attrill.
The School of Dentistry at Birmingham is at the forefront of the new Internet technologies and has developed a series of Podcasts which are available for dental students to download via their iPod/ mp3 player.

The dental school is listed on iTunes and subscribers automatically receive new Podcasts when they become available. The School has also developed a series of portals for students to create, interact with and access web based information, without requiring any programming knowledge via its elearning environment (ecourse).

A Wiki was developed along the same principles as www.Wikipedia.com. Topics are placed on the site by either staff or students and the pages are further populated and edited by contributions from the whole student body. Blogs (web diaries) are also available for use. 


\section{DIARY}

January

1st International meeting on Cold

Laser Therapy in Dentistry

Date: 18 January 2007

Venue: New Orleans, USA

Tel/Fax: (888) 891-6485

\section{5th Annual North American}

Orthodontic Conference for Full

Face Orthodontic Study Group

Date: 19-21 January 2007

Venue: New Orleans, USA

Tel/Fax: (888) 891-6485

Setting up in practice

Date: 19 January 2007

Venue: BDA Lecture theatre

Tel: 02075634590

Email: events@bda.org

\section{February}

Moving to private practice conversion and beyond

Date: 23 February 2007

Venue: BDA, London

Tel: 02075634590

Email: events@bda.org

May

ADI 20th Anniversary Congress

Date: 3-5 May 2007

Venue: ICC in Birmingham

www.adi.org.uk

\section{BDA British Dental Conference} and Exhibition 2007

Date: 24-26 May 2007

Venue: Harrogate International

Centre (HIC)

Tel: 02075634590

Email: events@bda.org

June

\section{4th Annual Congress of the} Turkish Dental Association

Date: 11-17 June 2007

Venue: Lütfi Kirdar Convention Center, Istanbul, Turkey

Email: tdbkongresi.com

www.tdbkongresi.com

\section{Teachers and trainers recognised}

The Dental Defence Union (DDU) has announced the three award-winners in its annual Educational Awards after a closely fought contest. The winner in the DCP Teacher of the Year was Sheila Phillips, School of Professionals Complementary to Dentistry, Portsmouth. The Dentist Teacher of the Year winner was Mark Greenwood, University of Newcastle, and VT Trainer of the Year was won by Mike Kelly of Kent, Surrey and Sussex Deanery.

Rupert Hoppenbrouwers, head of the DDU, presented all six finalists with a certificate, trophy and a cheque for $£ 250$ at the fourth awards event in London. The winners also received $£ 1000$ towards the cost of educational materials for their schools or VT schemes. Mr Hoppenbrouwers said, "Our congratulations to all the finalists and particularly to Sheila Phillips, Mike Kelly and Mark Greenwood who have so clearly demonstrated the many ways in which the best dental teachers and trainers can motivate and inspire their students and trainees."

During the event, the finalists in the Dentist and DCP Teacher of the Year categories went head-to-head to demonstrate the innovative ways in which they had made a positive educational impact on students.
These included the use of online learning, mentoring, actor patients with whom students could practice taking clinical histories, and even a dental version of the television quiz, Who Wants to be a Millionaire. Following the presentations, the two finalists in each category were quizzed by the judging panel and by the audience about their work, including how they responded to difficult students; the benefits and limits of technology in teaching; and how they ensured that students recognised their ethical and professional obligations.

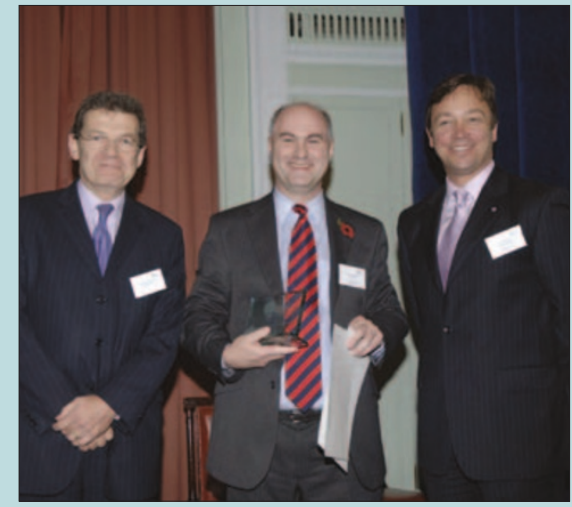

Left to right, Rupert Hoppenbrouwers, Head of the DDU, Mark Greenwood, winner Dentist Teacher of the Year and Peter Rees, General manager, Dentsply.

\section{Effective infection control to prevent exposure to HIV}

The FDI is encouraging safe dental practices to prevent the spread of HIV/AIDS.

According to the organisation, from high-tech dental offices to simple village health posts, oral health professionals are at risk daily of both spreading and contracting HIV/AIDS.

It says that even in resource-poor settings, effective infection control is possible, as outlined in a guide on Infection Control for the Delivery of Basic Oral Emergency Care that was recently published in the FDI's Developing Dentistry journal.

Invasive interventions, performed regularly by dentists, can expose practitioners to the virus. Only effective infection control measures in all clinical settings can prevent the spread of the HIV virus and other highly infective diseases.

The FDI World Dental Federation strongly encourages effective and routine hygiene measures and encourages the development of ways to prevent cross-infection with any disease.

It says there are strong links between oral health and HIV/AIDS both for early diagnosis and therapy. The oral manifestations of the infection have a high impact on the quality of life of patients and their nutrition status, and the organisation believes that helping them by controlling these oral lesions is an important role of the dentist and his team.

In July this year, the FDI and the Organization for Safety and Asepsis Procedures (OSAP) agreed on a detailed cooperation programme to enhance infection control and safety practices in dentistry worldwide, to help protect dental professionals from occupational risks, and to provide safe dental care for patients. 